\title{
For Academic Community Free From Tobacco Smoking
}

\author{
Romana Caput-Jogunica, Sanja Ćurković \\ University of Zagreb, Zagreb, Croatia
}

\begin{abstract}
Adolescence and early adult age are key periods for the development of the habits which can have far-reaching consequences during the whole life. The environment greatly influences smoking habits. The purpose of this paper is to draw attention to prevalence of students' smoking behaviour and the role of academic community in preventing and combating smoking. On average, 10\%-15\% students start smoking during studies. The increased number of smokers can be linked to students' rich social life, so-called "smoking as a social tool" with coffee, alcohol, etc. The role of academic community is important in preventing the development of typical addictive behaviour in students. Students are aware of harmful effects that smoking has on their health and they generally try to ignore it until serious symptoms appear; on the other hand, the majority of them is, due to smoking, well accepted by their peers which is consequently demotivating for students who want to quit. The determinants of legislation regarding smoking ban in higher education institutions, are very often reduced to placing signs of non-smoking area on the entrances of the institutions. We conclude that the mobilization of the whole academic community is needed in cooperation with health services in the implementation of preventive measures and combating smoking.
\end{abstract}

Keywords: university students, smoking habits, prevention

\section{Introduction}

For young people, the period of enrolment at university represents a certain excitement and challenge. New responsibilities, greater degree of independence and freedom are big changes which are often accompanied by the new environment, less parental control, making new friendships, and similar factors. The transition from childhood into adulthood is characterized by the change in attitudes, social relations and the responsible behaviour towards personal health. Although in that period youngsters estimate their general health condition as good, their acquired life habits are different and are not always favourable for their health. Experts emphasize that it is more important to monitor the presence of various types of risky behaviour in the population than to focus on specific illnesses because one risk factor can result in the occurrence of several types of illnesses. For example, smoking, as one of the leading risk factors, causes or contributes to the emergence of coronary or respiratory, malignant, neurological and other diseases. World Health Organization (WHO) warns that almost $80 \%$ of adult smokers begin their smoking experience before the age of 18 . It is estimated that every day more than 4,000 adolescents worldwide light their first cigarette, and that one third of young people will develop smoking syndrome (Rodriguez \& Audrian-McGovern, 2005).

Romana Caput-Jogunica, Ph.D., Associated Professor of Physical Education, Department for Physical Education, Faculty of Agriculture, University of Zagreb, Zagreb, Croatia.

Sanja Ćurković, Ph.D., Assistant Professor of Physical Education, Department for Physical Education, Faculty of Agriculture, University of Zagreb, Zagreb, Croatia. 
Approximately one third of Croatian citizens smoke, and 57.9\% smoke more than 20 cigarettes per day. The worrying fact within age groups is that the greatest amount of smokers ranges between 18 and 29 years old (Samaržić, 2009). Adolescence and early adult age are the key periods for the development of the habits which can have far-reaching consequences during the whole life. The environment greatly influences on smoking habits. Smoking expenses frequently have impact on the quality of life of other members of the family. In family budget in which one member is a smoker, approximately $7 \%$ of the available family budget is spent on tobacco, which influences the quality of life of other family members (Wang, 2006).

The purpose of this paper is to draw attention to prevalence of students' smoking behaviour and the role of academic community in preventing and combating smoking. The infrastructures of academic community (higher education institutions, campuses and its student support centres and services as well as other systems of support) allow higher education institutions to provide activities that we can raise students' awareness about protecting health and to motivate their behaviour change.

Preference of sedentary lifestyle among university students and unsatisfactory level of physical activity is increasingly becoming a growing problem among youth. Besides that, the epidemiological studies about smoking habits have highlighted a high percentage of smokers aged 18 to 24 . According to Podstawski, Choszcz, Klimczak, Kolankowska, and Žurek (2014), there is a lower percentage of smokers in the student population (22.7\%) compared to those who are not involved in education system (40.6\%). Analyzing the role of the academic community in preventing and combating smoking habits in the community, it is important to emphasize the specificity of the Croatian higher education curricula related to mandatory Physical Education in Bachelor's Programme (Bs), during the first and second year of study. Physical Education (PE) is the only subject with the content that encourages students to take care of their own health. One of the PE curriculum tasks is to inform students about negative impacts of risk behaviour on their health (Neljak \& Caput-Jogunica, 2012). The Republic of Croatia has developed the legislation ${ }^{1}$ and basic infrastructure for strengthening supervision of tobacco. According to the "Law on the restriction of the use of tobacco and related products": "the prohibition of smoking tobacco and related products is declared for all closed public spaces"; smoking is also prohibited on the premises which are not considered as closed public spaces under this Law and are a functional part of the area where the activity of education is carried out. The main aim in the "Action plan for strengthening of the use of tobacco 2013-2016" was to improve health of the Croatian citizens by adopting non-smoking habits as healthy lifestyle.

\section{A Review of Studies About Prevalence of Smoking in Student Population}

In the Republic of Croatia, there are $48.1 \%$ of male students and $38.4 \%$ of female students aged 18 to 29 who smoke every day. According to Samaržić (2009), Croatia follows the trend of West European countries

with high prevalence of male smokers (37.9\%), but with high percentage of female smokers (25.1\%); smoking begins in early adolescence according to the same behaviour patterns for all participants; the problem is that our society tolerates smoking and young people with cigarettes do not find much peer pressure to stop.

\footnotetext{
${ }^{1}$ Law on the restriction of the use of tobacco and related products ("Narodne novine", broj 125/2008, 55/2009 - ispravak i 119/2009), https://www.zakon.hr/z/909/Zakon-o-ograni\%C4\%8Davanju-uporabe-duhanskih-i-srodnih-proizvoda. The health care law ("Narodne novine", broj 150/2008, 71/2010, 139/2010, 22/2011, 84/2011, 12/2012, 35/2012, 70/2012 i 144/2012) https://narodne-novine.nn.hr/clanci/sluzbeni/2018_11_100_1929.html. Health inspection law ("Narodne novine", broj 113/2008 i 88/2010) https://www.zakon.hr/z/344/Zakon-o-sanitarnoj-inspekciji.

2 Article 25, points 2 i 4.
} 
The study by Ćurković (2010) conducted on the sample of 1,651 students of the University of Zagreb determined that $28.3 \%$ students smoke every day. Most students started smoking between the ages of 14 to 17 . The most frequent reasons for smoking are the following: sense of personal satisfaction (28.6\%), overcoming boredom (15.1\%) and stress (13.8\%) as well as the sense of a better concentration (5.75\%). This study also confirmed significant differences in gender concerning the amount of cigarettes, with male students smoking more than female. However, there was an increase in the number of female students smoking up to 10 cigarettes per day. Although no significant differences were found in smoking habits regarding the age, the author emphasizes the highest prevalence of smoking between the ages of 19 to 22 which can be explained by students' rich social life. The analysis of differences in smoking according to fields of science has shown the highest prevalence of smoking in students of biotechnical sciences, then in biomedicine, social and technical field of science. The lowest prevalence of smoking was found in students in the field of humanities and natural sciences.

Bedeković, Brlas, Šerepac, and Venus (2015) conducted the study on the sample of 171 undergraduate vocational students in Virovitica with the aim to collect data about smoking habits and other types of risk behaviour, students' attitudes and behaviour regarding these factors. The $83.6 \%$ students thought that more than half of the students smoke. The most common reasons are: "to feel good" and "because others smoke". In comparison with male students (35.9\%), a higher percentage of female students smoke tobacco regularly (45.85\%). The trend of students smoking has been confirmed in the pilot study on the sample of 668 students of the University of Zagreb Faculty of Agriculture (379 freshmen: 120 male and 259 female and 289 second year students: 89 male and 200 female) conducted in the frame of the mandatory PE in 2016/2017 academic year. The analysis determined that $31.1 \%$ of students smoke (218 students: 59 male and 159 female). These results confirm the above mentioned conclusions that the largest number of students started smoking at the age of 17 and the main reasons that we have already mentioned are: feeling satisfied, overcoming boredom and stressful situations. The $50.4 \%$ of the students tried to quit smoking at least once due to health problems.

Numerous research studies regarding students' smoking habits recognize the phenomenon of "smoking as a social tool" (Podstawski et al., 2014; Moran, Wechsler, \& Rigotti, 2004; Rollins, Malmstadt-Schumacher, \& Ling, 2002; Ling \& Glantz, 2004; Philpot et al., 1999).

Young people stated often that they smoke with friends or in the company when they go out, but they do not consider themselves smokers (Harris, Wilson, \& Ahluwalia, 2002; Waters, Harris, Hall, Nazir, \& Waigandt, 2006).

The study (Podstawski et al., 2014) conducted on the sample of 762 females from the University of Poland, showed that $65 \%$ female freshmen abstained from smoking, whereas $16.58 \%$ smoke from time to time depending on the situation. The most frequent reasons are: "it is fashionable" (76.24\%), "it helps to reduce nervous tension" (15.70\%), and "to make social contact" (7.66\%). In that review paper, the authors have compared results from different studies regarding current smoking situation on the sample of students in some European countries where majority of students are non-smokers: in Finland $83 \%$ and in Great Britain $71 \%$. In the countries in the Southeast of Europe, the data are a little bit different: for example, in the study conducted on the sample of 420 students in Bosnia and Herzegovina, 21\% of students are smokers of which the largest percentage (11.2\%) of students smoke from 10 to 20 cigarettes a day. As the main reason for smoking, $60 \%$ of students stated overcoming the everyday stressful situations (Branković, Pilav, Cilović-Lagarija, Pašalić, \& Mahmutović, 2017). 
The study carried out by Stojanović-Tasić, Grgurević, Trajković, and Pekmezović (2016) on the sample of 2,000 students from Serbia confirmed previously mentioned results regarding the age when majority of young people start smoking (at the age of 17) and differences regarding gender: $25.9 \%$ female smokers in comparison to $18.2 \%$ male smokers. The authors found that $90 \%$ of students used to stay in the same area with smokers and as passive smokers they are used to staying in smoker's area for an average of up to 5 hours a day. Daily smoking and frequent exposure to smoke may impact on reproductive health: "It increases the risk of infertility and pregnant women who smoke have greater risk of premature birth and miscarriage. Also, women who smoke have more frequent menstrual disorders and 2 to 3 years earlier menopause" (from the Action plan of tobacco control, 2013) ${ }^{3}$. In addition to that, the correlation with lung cancer of adults and obstructive pulmonary diseases in children was confirmed (Knežić \& Hudrović, 2014).

\section{Discussion: To Become or to Remain a (Non)smoker}

Summing up the results of studies in the last decade, we can conclude that despite numerous media campaigns concerning the serious health consequences of smoking, the smoking trend is not decreasing. It is alarming that the decreasing trend of smoking is not registered in medical students who will become future health care professionals. The results of the study by Schneidrova, Koprivova, Šustakova, and Hynčica (2016) conducted on the sample of 452 medical students (Bs and Ms study programs) confirm this conclusion.

At the time of the research, $18.9 \%$ of students of the Master's Programme (Ms) and $17.1 \%$ of students of the Bachelor's Programme (Bs) were occasional smokers. 5.9\% of students of the Ms and $19 \%$ of students of the Bs reported that they have not quit smoking during their studies at the medical faculty, on the contrary, $9.8 \%$ of students of the Ms and $14.3 \%$ of Bs has started smoking during that time.

The differences in answers between students of both study programmes and genders were not statistically significant. The $26.4 \%$ students of Ms and $75.9 \%$ students of Bs reported that they are familiar with the Smoking Cessation Councelling Centre at the Faculty. The studies by Knežić and Hudrović (2014) conducted on the sample of future health care professionals in the University of Dubrovnik do not significantly depart from these results.

According to the study of Subramaniam et al. (2015):

Several important factors: intrapersonal (age, ethnicity, risk perception, etc.) interpersonal (parental and peer smoking, parental attitudes, etc.) and environmental (legislation regarding smoking) are associated with tobacco usage and adoption of smoking habits among adolescents.

For a better understanding of the situation of young people addicted to smoking and their awareness of the impact that smoking may have on their health and quality of life, we are going to present some opinions of the students of the Faculty of Agriculture who had participated in the campaign "For the Faculty free of smoke". Once adopted smoking habits present a big challenge for a young person who wants to stop smoking.

I consider myself active smoker from the beginning of the study, when the level of stress in my life increased and when I bought my first pack of cigarettes. Although I am familiar with legislation regarding smoking, I am aware that I am addicted to smoking and it will not be easy for me to quit.

\footnotetext{
3 Akcijski plan za jačanje nadzora nad duhanom za razdoblje od 2013. - 2016. Republika Hrvatska, Ministarstvo zdravlja (2013) https://vlada.gov.hr/UserDocsImages//2016/Sjednice/Arhiva//74.\%20-\%2011.pdf.

${ }^{4} \mathrm{http} / / /$ www.agr.unizg.hr/hr/article/1780/kampanja_za_fakultet_bez_duhanskog_dima_lak\%C5\%A1e_\%C5\%BEivim_ak\%E2\%8 $0 \% 99 \_$ne_dimim.
} 
It is hard to say no forever, but when I come home and my clothes and hair smell like smoke, I ask myself if this is what I want, and the answer is no, but for some reason I do it again and again.

Unfortunately we can't make decisions for others, to quit smoking is an individual decision. The best way to motivate people to quit smoking is education.

The following authors Rigotti, Lee, and Wechsler (2000); Choi, Pierce, Gilpin, Farkas, and Berry (1997); Staten, Rayens, and Ridner (2007); Ćurković (2010); and Schneidrova et al. (2016), determined that on average $10 \%-15 \%$ students start smoking during studies. The increased number of smokers can be linked to rich social life of students, so-called "smoking as a social tool" with coffee, alcohol, etc. (Samaržić, 2009). According to students' subjective assessment, smoking cigarettes helps them to overcome stressful situation and to enhance concentration and learning. Active substance in cigarette (nicotine) creates the sense of satisfaction, reduces stress and feelings of tension and contributes to a sense of easier fulfilment of daily obligations. Some studies (Kear, 2002; Lenz, 2004 cf. Ćurković, 2010; Samaržić, 2009; and Stojanović-Tasić et al., 2016) link smoking predisposition with low self-esteem and anamnesis of anxiety and depression.

\section{The Role of Academic Community in Smoking Control}

The question is how to effectively influence and combat smoking among student population. The role of academic community is important, because it is reasonable to take actions that can preventively influence the development of typical addictive behaviour in students (Samaržić, 2009). Specific objectives of the "Action plan for strengthening the control over tobacco 2013-2016" are focused on education of young people "to resist temptation and to make right decisions regarding smoking" and "reducing exposure to tobacco smoking in public places, workplaces and home environment". The determinants of legislation regarding smoking ban in higher education institutions are very often reduced to placing signs of non-smoking area on the entrances of institutions. Following WHO and European Union documents, the promotional activities regarding health care are being implemented in the European universities in recent years. Promotional campaigns, educational activities, and smoking cessation consultancy for members of the academic community are being implemented at medical faculties in Prague with the aim to combat smoking in faculties and hospitals. For the students who are considering quitting smoking, the Faculty offers support in the Students Counselling Centre (Schneidrova et al., 2016).

Higher education institutions should continuously provide the activities and measures which will raise awareness about negative impacts of smoking not only on health, which young people ignore, but also on work capacity and reproductive health (Subramaniam et al., 2015). Mobilization of the academic community in cooperation with health services is necessary, but only if anti-smoking regulations are conducted consistently with advisory and expert services to help students who are motivated to quit. Most of the Croatian higher education institutions have established various kinds of support centres (career counselling, support for students with disabilities, peer support, etc.). In the frame of these centres and in cooperation with health services and PE professors, education programs about self-control techniques, stress management, establishing better concentration and social communication without cigarettes could be continuously provided. Higher education institutions which provide health and education study programs as well as consistent implementation of legislation in practice should be the (leading, chief) promoter of combat and prevention of smoking. Higher education institutions which provide study programs regarding health, education as well as consistent implementation of legislation in practice should be program holders for combating and prevention of smoking. 


\section{Conclusions}

Smoking addiction is a global epidemic that has harmful consequences for health: it may influence the development of a great number of diseases; it reduces productivity and contributes to mortality (Action plan of tobacco control, 2013) $)^{5}$. This paper presents the data from studies that have been confirmed with a certain percentage of students who start smoking at the beginning or during their studies for the following reasons: to overcome tension, stressful situation or boredom, to improve concentration, for satisfaction, and to establish communication. It takes several years for young person who smokes to become addicted. According to students' opinions obtained from the campaign "For the Faculty free of smoking" at the Faculty of Agriculture in Zagreb, we can conclude that for changes of smoking habits, smoking cessation and eventually quitting smoking it is necessary to mobilize the whole academic community with the aim to ensure consistent implementation of the laws and regulations and to offer support and education for students who are motivated to quit smoking. Podstawski et al. (2014) and Sukys, Cesnaitiene, and Ossowsky (2017) have identified the lack of competencies regarding students' health literacy (knowledge about health care services, prevention of diseases and health promotion) related to age and level of education. At Croatian higher education institutions, PE is mandatory subject at the majority of faculties for students in the first and second years of study. As part of health culture to fulfil the task that has been defined by the curriculum, we can organize attractive workshops for students with the aim to inform them about dangers that smoking can have on their health and quality of life.

With this paper, we want to point out the problem of frequent smoking among students and the vicious circle in which young people find themselves: on the one hand, they are aware of harmful effects that smoking has on their health and they try to generally ignore it until serious symptoms appear; on the other hand, the majority of them is well accepted for smoking by their peers which is consequently demotivating for students who want to quit. We conclude that the mobilization of the whole academic community in cooperation with health services is needed in the implementation of preventive measures and combating smoking. Good examples of practice need to be consistently implemented in the legislation on smoking bans in all public enclosed spaces. Finally, it is necessary to provide professional support for students who want to quit smoking at the established centres in higher education institutions.

\section{References}

Bedeković, V., Brlas, S., Šerepac, V., \& Venus, M. (2015). Istraživanje o pušenju, alkoholu, kockanju, drogama i slobodnom vremenu. Retrieved from http://vsmti.hr/wp-content/uploads/2017/11/Istrazivanje-o-pusenju-alkoholu-drogama-kockanju-islobodnom-vremenu-u-VMTI-2015.pdf

Branković, S., Pilav, A., Cilović-Lagarija, Š., Pašalić, A., \& Mahmutović, J. (2017). Lifestyles of university students in Bosnia and Herzegovina. Journal of Health Sciences, 7(1), 27-34.

Choi, W. S., Pierce, J. P., Gilpin, E. A., Farkas, A. J., \& Berry, C. C. (1997). Which adolescent experimenters progress to established smoking in the United States. American Journal of Preventive Medicine, 13(5), 385-391.

Ćurković, S. (2010). Kineziološke aktivnosti i rizična ponašanja studenata (Disertacija, Sveučilište u Zagrebu Kineziološki fakultet).

Harris, K. J., Wilson, T., \& Ahluwalia, J. S. (2002). Qualitative analysis of college students' smoking: Perceptions and interest in change. Proceedings from Annual Meeting of the Society for Research on Nicotine and Tobacco. Savannah, GA.

Kear, M. E. (2002). Psychosocial determinants of cigarette smoking among college students. Journal of Community Health Nursing, 19(4), 245-257.

\footnotetext{
5 Akcijski plan za jačanje nadzora nad duhanom za razdoblje od 2013. - 2016. Republika Hrvatska, Ministarstvo zdravlja (2013) https://vlada.gov.hr/UserDocsImages//2016/Sjednice/Arhiva//74.\%20-\%2011.pdf.
} 
Knežić, M., \& Hudrović, N. (2014). Učestalost pušenja u studentskoj populaciji. Sestrinski glasnik, 19(1), 12-16.

Lenz, B. K. (2004). Tobacco, depression and lifestyle choices in the pivotal early college years. Journal of American College Health, 52(5), 213-219.

Ling, P., \& Glantz, S. (2004). Tobacco industry research on smoking cessation. Journal of General and International Medicine, 19(5), 419-426.

Moran, S., Wechsler, H., \& Rigotti, N. A. (2004). Social smoking among US college students. Pediatrics, 114(4), 1028-1034.

Neljak, B., \& Caput-Jogunica, R. (2012). Kineziološka metodika u visokom obrazovanju. Sveučilište u Zagrebu Kineziološki fakultet. Recenzirani interni nastavni materijal.

Philpot, S. J., Ryan, S. A., Torre, L. E., Wilcox, H. M., Jalleh, G., \& Jamrozik, K. (1999). Effect of smoke-free policies on the behaviour of social smokers. Tobacco Control, 8(3), 278-281.

Podstawski, R., Choszcz, D., Klimczak, J., Kolankowska, E., \& Žurek, P. (2014). Habits and attitudes of first-year female students at Warmia and Mazury University: A call for implementing health education programme at universities. Cent Eur $J$ Public Health, 22(4), 229-238.

Rigotti, N. A., Lee, J. E., \& Wechsler, H. (2000). US college students' use of tobacco products: Results of a national survey. JAMA, 284(6), 699-705.

Rodriguez, D., \& Audrian-McGovern, J. (2005). Physical activity, global physical self-concept and adolescent smoking. Annals of Behavioral Medicine, 30(3), 251-259.

Rollins, S., Malmstadt-Schumacher, J. R., \& Ling, P. M. (2002). Exploring the phenomenon of social smoking—Why do so many young adult socially smoke? Proceedings from National Conference on Tobacco or Health. Los Angeles, CA.

Samaržić, S. (2009). Breme pušenja u populaciji mladih odraslih (Doktorska disertacija, Sveučilište Josipa Jurja Strossmayera u Osijeku, Medicinski fakultet).

Schneidrova, D., Koprivova, H., Šustakova, M., \& Hynčica, V. (2016). Smoking habits and attitudes in students of the Third Faculty of Medicine of Charles University in Prague. Cent Eur J Public Health, 24(2), 144-151.

Staten, R., Rayens, M. K., \& Ridner, S. L. (2007). Social influences on cigarette initiation among college students. American Journal of Health Behavior, 31(4), 353-362.

Stojanović-Tasić, M., Grgurević, A., Trajković, G., \& Pekmezović, T. (2016). Influence of family smoking habits and passive smoking on smoking status among Belgrade University students. Substance Use \& Misuse, 51(3), 310-317.

Subramaniam, M., Shahwan, S., Fauziana, R., Satghare, P., Picco, L., Vaingankar, J. A., \& Chong, S. A. (2015). Perspectives on smoking initiation and maintenance: A qualitative exploration among Singapore youth. Int. J. Environ. Res. Public Health, 12(8), 8956-8970.

Sukys, S., Cesnaitiene, V. J., \& Ossowsky, Z. M. (2017). Is health education at university associated with students' health literacy? Evidence from cross-sectional study applying HLS-EU-Q. BioMed Research International.

Wang, H. (2006). Tobacco control in China: The dilemma between economic development and health improvement. Salud Publica de Mexico, 48(Supl.1), S140-147.

Waters, K., Harris, K., Hall, S., Nazir, N., \& Waigandt, A. (2006). Characteristics of social smoking among college students. Journal of American College Health, 55(3), 133-139.

World Health Organization. (2010). WHO advisory note: Information for the media, smoking patterns in Europe. Retrieved from http://www.euro.who.int/en/what-we-publish/information-for-the-media/sections/features/2010/01/women-and-tobacco/smok ing-patterns-in-europe 